TITLE:

HIPPOLYSMATA GRABHAMI GORDON, A SYNONYM OF LYSMATA AMBOINENSIS (DE MAN) (DECAPODA, CARIDEA, HIPPOLYTIDAE)

$\operatorname{AUTHOR(S):~}$

Hayashi, Ken-Ichi

CITATION:

Hayashi, Ken-Ichi. HIPPOLYSMATA GRABHAMI GORDON, A SYNONYM OF LYSMATA

AMBOINENSIS (DE MAN) (DECAPODA, CARIDEA, HIPPOLYTIDAE). PUBLICATIONS OF THE SETO MARINE BIOLOGICAL LABORATORY 1975, 22(5): 285-296

ISSUE DATE:

1975-11-29

URL:

http://hdl.handle.net/2433/175900

RIGHT: 


\title{
HIPPOLYSMATA GRABHAMI GORDON, A SYNONYM OF LYSMATA AMBOINENSIS (DE MAN) (DECAPODA, GARIDEA, HIPPOLYTIDAE)
}

\author{
KEN-IGHI HAYASHI \\ The Shimonoseki University of Fisheries, Yoshimi, \\ Shimonoseki, Yamaguchi-ken, Japan \\ With Plate $V$ and Text-figures $1-4$
}

While we were engaged in the faunal research of the Kushimoto Marine Park and its neighbourhood, a single beautiful shrimp was captured by one of my colleagues at about $20 \mathrm{~m}$ deep near Myogajima Island, Kushimoto on December 8, 1973. At a glance, it was mistaken for a kind of the stenopodean shrimp, because it occurred at just the entrance to a rock crevice near the bottom, where Stenopus hispidus (Olivier), the common stenopodean shrimp from the middle Japan, had been usually observed. The captured shrimp was, however, distinguished apparently from $S$. hispidus by its more brilliant and differently striped color pattern and its slenderer non-chelate third pair of pereiopods. Its general appearance obviously showed that it was referable to a member of the caridean group, which had not been known from the Japanese waters so far. Then it was reared alone in a small plastic bucket for some time without being examined for further taxonomical studies. On the tenth day of rearing, however, it happened that the shrimp was found completely moulted in the bucket and then it was moved into a large aquarium, in which three species of moray eels and one snake eel had been exhibited. As soon as the shrimp just released in the large aquarium touched one of moray eels with its antennal flagellum, it started positively cleaning the body surface and even the inside of the mouth of that fish.

Close examination of the empty shell castoff at moulting assigned the present shrimp to the hippolytid shrimp, Lysmata amboinensis (De Man). On the other hand, its cleaning behavior and color pattern as well as its external morphology were all well in accordance with those of Hippolysmata grabhami Gordon, originally described from the Atlantic Ocean, but then reported four times from the Indo-West Pacific region, too, under the name, Hippolysmata (or Lysmata) grabhami (Randall, 1958, Feder, 1966, Faulkner and Smith, 1970 and Bruce, 1974). Thus, Lysmata amboinensis and Hippolysmata grabhami seemed to be synonymous with each other. Very fortunately through the courtesy of Dr. R. W. Ingle of the British Museum, Natural History, London and Prof. Dr. L. B. Holthuis of the Rijksmuseum van Natuurlijke 
Historie, Leiden, some obscure points and unusual features of Hippolysmata amboinensis and $H$. grabhami respectively, found in their original descriptions were checked and confirmed, and this resulted in to prove that $H$. grabhami is a synonym of L. amboinensis.

The present paper is to give the detailed taxonomical accounts on the castoff shell of Lysmata amboinensis (De Man), which is new to the Japanese fauna, and to record a short observation of its fish cleaning behavior in an aquarium.

I am much indebted to Dr. R. W. Ingle of the British Museum, Natural History, London for the reexamination of the holotype of Hippolysmata grabhami and the loan of a paratype, and also to Prof. Dr. L. B. Holthuis of the Rijksmuseum van Natuurlijke Historie, Leiden for the reexamination of the holotype of Hippolysmata amboinensis. Thanks are also due to Prof. T. Tokioka of the Seto Marine Biological Laboratory, Kyoto University for his critical reading of the manuscript.

\section{Lysmata amboinensis (De Man)}

(Figs. 1-4, pl. V)

Hippolysmata vittata amboinensis De Man, 1888, p. 495.

Hippolysmata amboinensis De Man, 1907, p. 426.

Hippolysmata grabhami Gordon, 1935, p. 319, figs. 10, 11.

Hippolysmata (Hippolysmata) amboinensis Holthuis, 1947, pp. 19, 70, figs. 12-14.

Hippolysmata grabhami Holthuis, 1947, p. 19 (list).

Hippolysmata grabhami Randall, 1958, p. 334.

Hippolysmata (Hippolysmata) grabhami Limbaugh, Pederson and Chace, 1961, p. 247, figs. 5, 6.

Hippolysmata grabhami Feder, 1966, p. 361, figs. 9 c, 11.

Hippolysmata grabhami Faulkner and Smith, 1970, pp. 74, 139, 1 pl., 1 fig.

Hippolysmata (Hippolysmata) amboinensis Zarenkov, 1971, p. 180.

Lysmata grabhami Chace, 1972, p. 128.

Lysmata grabhami Bruce, 1974, p. 107, 1 fig.

Lysmata grabhami Bruce, 1975, p. 26, fig. 10.

Description of the castoff shell. The body is about $45 \mathrm{~mm}$ in length. The carapace is $10.9 \mathrm{~mm}$ and the rostrum is $9.0 \mathrm{~mm}$ in length. The latter reaches slightly beyond the second segment of the antennular peduncle and is armed along the upper margin of the proper part with five teeth spaced regularly, followed by a tooth situated widely apart from the posterior-most rostral tooth on the middorsal line of the carapace, while along the lower margin with three teeth situated distal to the second tooth of the upper series. The antennal spine and the pterygostomial spine are both well developed, but the latter is much smaller than the former (Fig. 1 a).

The abdomen is rounded dorsally. The pleura of the first three somites are rounded but those from the fourth to sixth somites are sharply pointed posteriorly. The sixth somite is 1.7 times as long as the fifth somite (Fig. $1 b$ ). The telson is 1.4 times as long as the sixth somite, with two pairs of the dorsal spines, of which the anterior pair is placed a little anterior to the middle, while the posterior pair just at the posterior one-third of the telson (Fig. 1 c). The outer margin of the telson is 


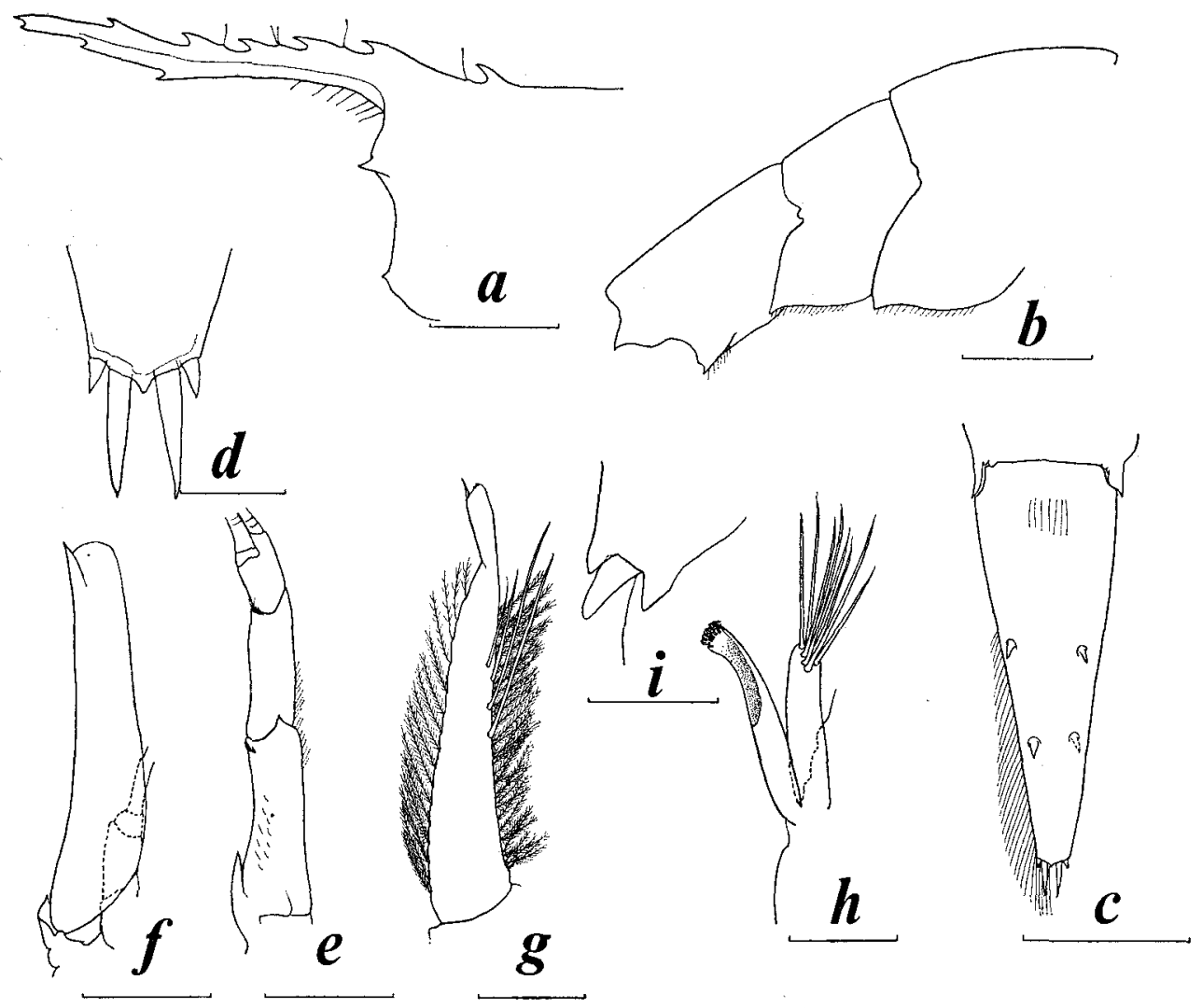

Fig. 1. Lysmata amboinensis (De Man), $a$, anterior part of carapace, $b$, fourth to sixth abdominal somites, $c$, telson, $d$, apex of telson, $e$, antennular peduncle, $f$, antennal scale, $g$, endopod of first pleopod, $h$, appendices interna and masculina, $i$, outer terminal spines on exopod of uropod. Scales for $a-c, e, f$ represent $3 \mathrm{~mm}$ and those for $d, g-i$ represent $0.5 \mathrm{~mm}$.

straight and the half posterior to the level of the anterior dorsal spines is furnished with a series of long hairs. The posterior margin is pointed at the middle and flanked by two pairs of spines (Fig. $1 d$ ).

The eyes are broken. The antennular peduncle is slender, reaching with the distal segment beyond the rostrum. The first segment is less than half as long as the carapace and slightly shorter than the distal two segments combined. The stylocerite is small and pointed at the inner distal corner. The second segment is twice as long as the third segment (Fig. $1 e$ ). The flagella are both slender and more than five times as long as the carapace. The outer flagellum is naked in the basal 10 joints, but setose in the following 18 joints. The antennal scale reaching slightly beyond the end of the antennular peduncle and five times as long as broad. The basicerite is provided with a spine. The carpocerite is short, not reaching the basal third of the scale (Fig. $1 f$ ). The flagellum is more than seven times as long as the carapace.

The mandible is simple, without a mandibular palp or an incisor process. The molar process ends in a stout process with some distinct denticulations (Fig. $2 a, a^{\prime}$ ). 
The maxillule has the slender proximal endite; the distal endite is much broader and the palp is indistinctly divided at apex (Fig. $2 b$ ). The distal endite of maxilla is divided into two lobes, the proximal endite is reduced to a small lobe, though with some long setae, and the palp and the scaphognathite are well developed (Fig. $2 c$ ). The first maxilliped has only the large distal endite, the proximal endite being unrecognizable; the palp is well developed and composed of three segments; the caridean lobe is also well developed; the exopod is long and the epipod is broad and bilobed (Fig. $2 d$ ). The second maxilliped is provided with the well developed exopod, broad epipod and the small podobranch (Fig. $2 e$ ). The third maxilliped reaches with the ultimate and half penultimate segments beyond the antennal scale. The ultimate segment is 1.4 times as long as the penultimate segment. The antepenultimate segment is more than twice as long as penultimate segment, with the well developed exopod.

The branchial formulae are as follows:

\begin{tabular}{lccc} 
& \multicolumn{3}{c}{ Maxillipeds } \\
Pleurobranchs & 1 & 2 & 3 \\
Arthrobranchs & - & - & - \\
Podobranchs & - & - & 2 \\
Epipods & - & 1 & - \\
Exopods & 1 & 1 & 1 \\
& 1 & 1 & 1
\end{tabular}

\begin{tabular}{cccccc}
\multicolumn{5}{c}{ Pereiopods } \\
- & 1 & 2 & 3 & 4 & 5 \\
-1 & 1 & 1 & 1 & 1 & 1 \\
1 & - & - & - & - & - \\
1 & - & - & - & - & - \\
& 1 & 1 & 1 & 1 & - \\
& - & - & - & - & -
\end{tabular}
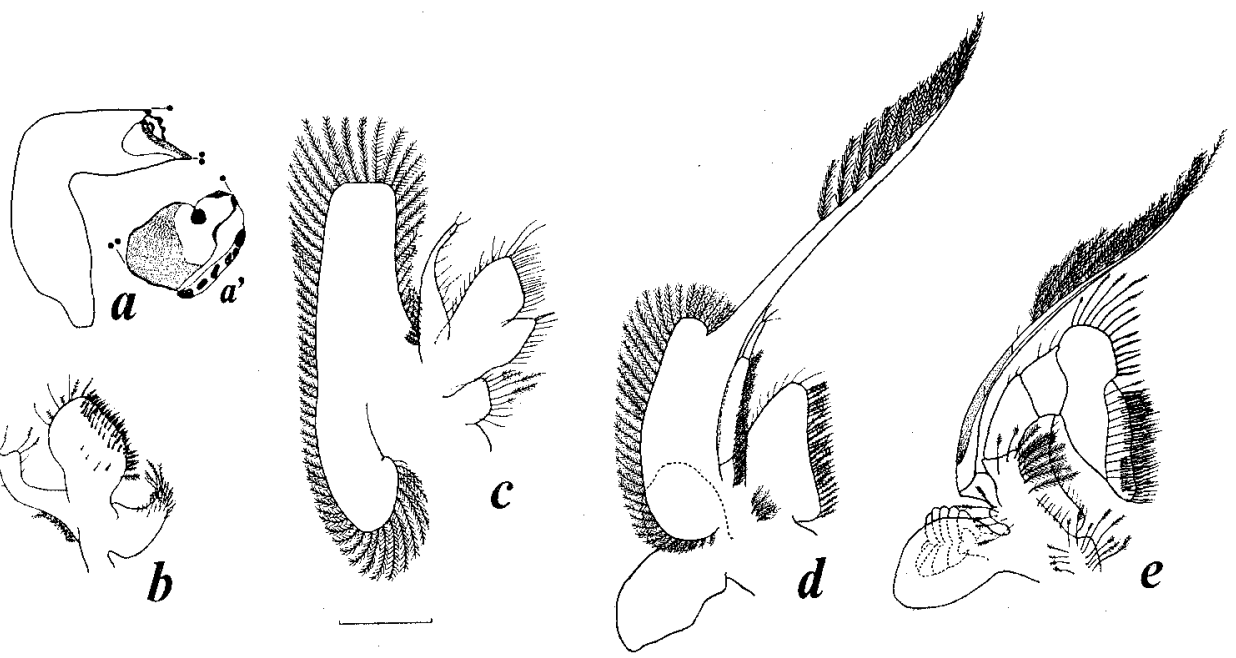

Fig. 2. Lysmata amboinensis (De Man), $a$, mandible, $a^{\prime}$, molar surface of mandible, $b$, maxillule, $c$, maxilla, $d$, first maxilliped, $e$, second maxilliped. Scale represents $1.0 \mathrm{~mm}$ in $a-e$ and 0.5 $\mathrm{mm}$ in $a^{\prime}$.

The first pereiopod reaches with the chela beyond the antennal scale. The chela is slender, the palm is 2.3 times as long as the fingers. The carpus is 1.2 times as long as the palm. The merus is 1.3 times as long as the carpus. The second pereiopod reaches with the chela and carpus beyond the antennal scale. The chela 
is slender and small, and the palm is longer than the fingers. The carpus is about 7 times as long as the chela and composed of 19 or 20 joints. The merus is about half as long as the carpus and subdivided into 8 joints. The ischium is as long as the merus and subdivided into 3 joints. The third pereiopod reaches with the distal three segments beyond the antennal scale. The dactylus is short, with four spines on the posterior margin. The propodus is long, 8.5 times as long as the dactylus and provided with 17 or 18 spinules on the posterior margin. The carpus is two-thirds the length of the propodus. The merus is 1.3 times as long as the propodus, with four or five spines on the outer surface. The fourth pereiopod reaches with the dactylus, propodus and two-thirds of the length of the carpus beyond the antennal scale. The dactylus is short, with four spinules on the posterior margin. The propodus is 8 times as long as the dactylus and armed with 13 spines on the posterior margin. The carpus is as long as that of the third pereiopod. The merus is 1.1 times as long as the propodus and provided with three or four spines on the outer surface. The fifth pereiopod reaches with the distal two segments beyond the antennal scale. The dactylus is broken off. The propodus is slightly shorter than that of the fourth pereiopod, with nine spines on the posterior margin. The merus is a little shorter than the propodus and provided with two outer spines.

The endopod of the first pleopod is tapered and about half as long as the exopod. The second pleopod equally biramous (Fig. $1 \mathrm{~g}$ ). The endopod is provided with the appendix interna and the appendix masculina. The appendix masculina is short and ends in eight long, simple setae. The appendix interna is slightly longer than the appendix masculina and its distal half is scooped and with many retinacula at the apex (Fig. 1 h). The uropod is as long as the telson. The outer margin of the exopod is terminated in three spines, of which the inner and outer ones are fixed, while only the middle is movable (Fig. $1 i$ ). The diaeresis is well marked. The abdominal sternites are unarmed.

Color. The color of the living specimen is most remarkable as well described and figured by Gordon (1935), Limbaugh, Pederson and Chace (1961) and Bruce (1974), and as seen in color plates given by Faulkner and Smith (1970) and Bruce (1975).

Cleaning behavior. Even the fragmentary observations made in the aquarium revealed some interesting facts as to the cleaning behavior of $L$. amboinensis. In the large aquarium, $100 \times 100 \times 60 \mathrm{~cm}$ in size, two specimens of the dragon morey eel, Muraera pardalis, six specimens of the brutal moray, Gymnothorax kikado, a single specimen of the slender moray, G. thyrsoidens, four specimens of the snake eel, Myrichthys aki and a pair of the banded shrimp, Stenopus hispidus, were living together with the present specimen of L. amboinensis. The floor of the aquarium was covered with natural and artificial rocks arranged to form many small crevices and holes, in which the snake and moray eels hid themselves. The front and right sides of the aquarium are glass-windows for observation, the back wall is wholly covered with artificial rocks and the plain wall is left on the left side.

The cleaner shrimp was usually found still holding the head up at two or three regular places, where the vertical wall is somewhat sheltered by overhanging rock. 
The body of the shrimp was kept almost straight, with the distal part of the abdomen slightly bent anteriorly. The antennular flagella were naturally extended forward; the inner flagellum was stretched straight just forward, while the outer flagellum was turned somewhat outward or upward. The antennal flagellum was bent posteriorly. The third maxilliped was bent at right angles at the distal articulation of the antepenultimate segment. The first pereiopod was also bent perpendicularly at the merocarpal articulation. The second pereiopod was folded deeply at the merocarpal articulation. The above-mentioned posture seemed to correspond with the "resting position" noted in Stenopus hispidus by Yaldwyn (1966).

In action, the shrimp walked around slowly on the floor and wall, lashing the antennular and antennal flagella. Sometimes it stopped, bent down these flagella and scraped them from the base to the apex with its third maxillipeds. The movement of flagella seemed to attract three species of moray eels. As soon as the shrimp touched any part of their body with one of the flagella, they always reacted to it turning the head to the shrimp and opening the mouth wide. But the cleaner shrimp started its work in only half of such cases and again wandered about slowly in another half. When the shrimp climed the host fish, it walked over the fish body much more vividly and cleaned from the head to the tail or from the trunk to the head of the fish. As soon as the cleaning was begun on one fish, many other moray eels crowed around the shrimp, with their mouth open, but usually the cleaner shrimp neglected them. However, the shrimp, kept solitarily separated from fish for a few days, seemed to climb host fish more frequently and clean them continuously from one to another. While cleaning, the shrimp tapped incessantly the body surface of the host with third maxillipeds, picked something up and carried it to the mouth with both of the first two pereiopods. Such cleaning action was done in only 15-30 sec. Usually the inside of the mouth and the skin of the dorsal side of the body as well as the fold of the dorsal fin were cleaned most frequently, but rarely the ventral side of the body and even the lower surface of the lower jaw. The inside of the mouth was cleaned most remarkably, because the host fish certainly welcomed the shrimp, opening the mouth and never closing it before the shrimp left the host body. In cleaning the host mouth the shrimp occupied a corner of the mouth but keeping the posterior part of the body outside the mouth.

Moreover, it was regularly observed that moray eels not only never refused the cleaning behavior of the shrimp but also requested it. The snake eels reared together with moray eels, however, seemed to entirely neglect this cleaner shrimp. And the banded shrimp also together with moray eels did not show any cleaning behavior with these fish, but only in one case during the observations, when the shrimp did some cleaning-like behavior for very short time, less than $15 \mathrm{sec}$; this action might be an offensive behavior rather than a perfect cleaning one. L. amboinensis was reared in the aquarium for more than six months, but without any special preparation of food for it, though it was observed near the end of rearing that it snatched up pieces of sliced flesh of horse-mackerel, supplied as a food for moray and snake eels.

Remarks. As the presence or absence of the secondary ramus on the upper 
flagellum of the antennular peduncle is a variable character as already shown by Kubo (1951) and Chace (1972), it is considered that the genus Hippolysmata is a synonym of the genus Lysmata.

De Man (1888) created Hippolysmata vittata amboinensis on five specimens obtained from Amboina, but four of them are unfortunately missing at present. The only specimen, which is now the holotype, was well described and figured by Holthuis (1947) who kindly reexamined it again for my present study.

The following differences are found between the Holthuis' description of $H$. amboinensis and that of the present specimen.

(1) There are three teeth on the lower margin of the rostrum in the present specimen, but four in the holotype.

(2) The sixth abdominal somite is 1.7 times as long as the fifth somite in the present specimen, whereas 1.5 times in the holotype.

(3) The posterior margin of the telson is pointed at middle in the present specimen, but nothing is mentioned about this in the holotype.

(4) The first segment of the antennular peduncle is more than half as long as the carapace in the holotype, but less than half in the present specimen.

(5) The stylocerite reaches about $1 / 4$ of the length of the first segment in the holotype, but about $1 / 3$ in the present specimen.

(6) The third maxilliped reaches with more than half of its ultimate segment beyond the antennal scale and is provided with a rudimental exopod on the left side but none on the right side in the holotype, while in the present specimen that maxilliped reaches with half of the penultimate segment beyond the antennal scale and furnished with the well developed exopod on both sides.

(7) The carpus of the second pereiopod is 6 times as long as the chela in the holotype, but 7 times in the present specimen.

(8) The fifth pereiopod reaches beyond the antennal scale with $1 / 3$ of the length of the propodus in the holotype, but with distal two segments in the present specimen.

(9) The outer margin of the exopod of the uropod ends in two spines in the holotype but three spines in the present specimen.

(10) The holotype is only $30 \mathrm{~mm}$ in length but the present specimen attains to about $45 \mathrm{~mm}$.

All these differences, except for 3 and 9, seem to belong to only individual variations or variations with the specimen size or growth stage. The exopod of the third maxilliped (6) described by De Man (1888) on the syntypes was shown as "der Exognath erreicht kaum mehr als ein Viertel der Länge des Endognathen", and therefore the asymmetrical feature of the exopod of the third maxilliped in the holotype is thought to be an abnormality. As to (3) and (9), according to Dr. Holthuis' reexamination, "in the holotype, the posterior margin of the telson is damaged, only the short outer spines are present, but the posterior margin is partly still intact and could very well have ended in a median tooth" (Fig. 3 a), and "the outer margin of the exopod of the uropod ends in two fixed teeth with a movable spine in between" 

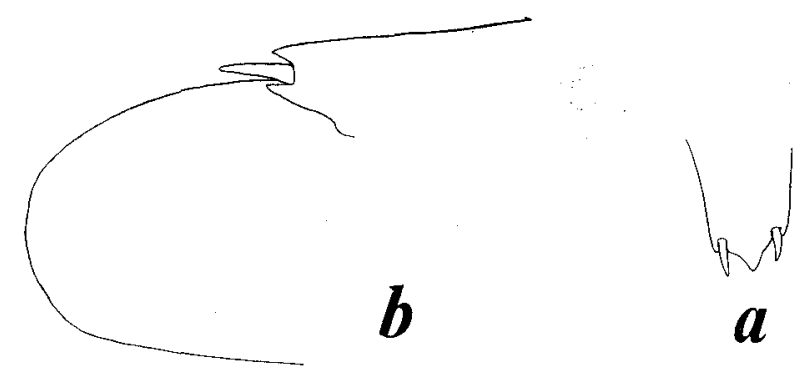

Fig. 3. Holotype of Hippolysmata amboinensis De Man, $a$, apex of telson, b, tip of uropodal exopod. After camera lucida sketches by Holthuis.

(Fig. $3 b)$.

On the other hand, the description and figures of the present species differ also from those of $H$. grabhami in the following points:

(1) According to the figures given by Gordon (1935) and Limbaugh, Pederson and Chace (1961), the pleuron of the fourth abdominal somite is rounded in $H$. grabhami, whereas it is sharply pointed in the present specimen and also in the description of $H$. amboinensis.

(2) The antennal scale is 3.5 times as long as broad in the holotype of $H$. grabhami, but 5 to 6 times in the present specimen and also in the holotype of $H$. amboinensis.

Dr. Ingle kindly reexamined the holotype of Hippolysmata grabhami to check the two points mentioned above and spared one of the paratypes to me for comparison.

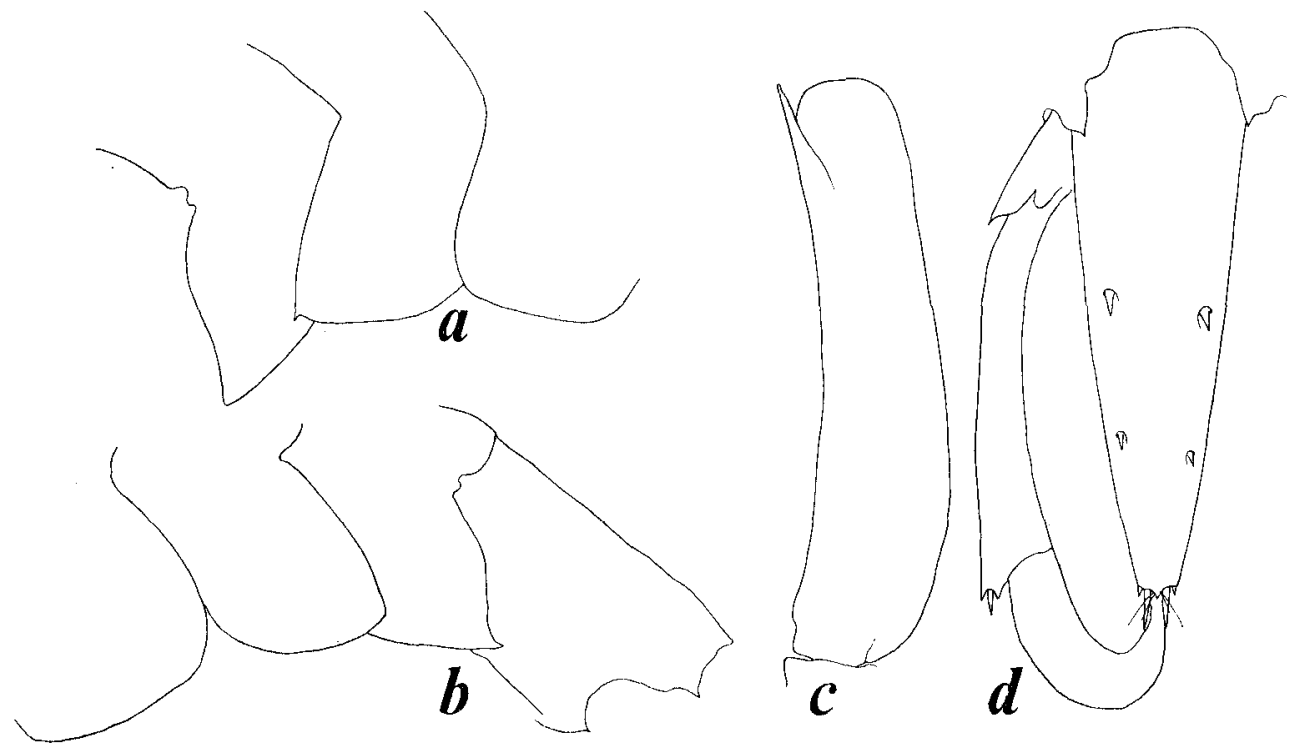

Fig. 4. Types of Hippolysmata grabhami Gordon, $a, b$, holotype, after camera lucida sketches by Ingle, $c, d$, paratype. $a$, right side of third to fifth abdominal somites, $b$, left side of third to sixth abdominal somites, $c$, antennal scale, $d$, telson. 
According to him, the pleuron of the fourth abdominal somite is rounded on the left side, but pointed on the right side in the holotype (Fig. $4 a, b$ ) as well as on both sides in paratypes. The antennal scale is 3.5 times as long as broad in the holotype as mentioned by Gordon (1935), but 4.2 times in the paratype examined (Fig. $4 c$ ). The length-width ratio of the antennal scale seems to vary with the specimen size, for the holotype of $H$. grabhami is the largest and with the $17 \mathrm{~mm}$ long carapace (after Gordon's figure) and the paratype examined is $14.6 \mathrm{~mm}$ in carapace length, while the holotype of $H$. amboinensis is the smallest, with only $6.0 \mathrm{~mm}$ long carapace (after Holthuis' figure) and the present specimen is $10.9 \mathrm{~mm}$ in carapace length. These explanations seem to justify that Hippolysmata grabhami is synonymous with Lysmata amboinensis (De Man).

L. amboinensis is closely related to the Indo-West Pacific species, L. multiscissa (Nobili), as mentioned by Monod (1969). The distinction between these two species was already referred to in detail by Monod (1969), as seen in the rostral formula that is $4-6+2-3 / 4-6$ in L. multiscissa while $5-7+1 / 3-5$ in L. amboinensis and the carpal segmentation of the second pereiopod that is $30-32$ in L. multiscissa while 17-23 in L. amboinensis. These characters seem to be constant.

Moreover, in the endopod of the first pleopod in male, the appendices interna and masculina are different in shape and ornamentation between the Monod's (1969) figure of $L$. multiscissa and that of the present specimen. In addition, these two species are apparently distinguishable from each other by color pattern: the coloration in L. multiscissa consists of "bandes longitudinales rouges" (Monod, 1969).

Monod (1969) regarded the existence of three terminal spines on the outer margin of the exopod of the uropod as one of the distinctive characters to separate L. multiscissa from L. amboinensis, but actually the uropodal exopod is furnished in L. amboinensis quite similarly as in L. multiscissa as mentioned above.

Apart from the morphologies of this cleaner shrimp, its natural behaviors have been observed and discussed well by Randall (1958) in the Papetoai Bay and the lagoon of Moorea at a depth of about 70 feet, by Limbaugh, Pederson and Chace (1961) at Florida Keys and in the Bahamas, by Feder (1966) in the Bahamas and by Faulkner and Smith (1970) in the Gulf of Aqaba at a depth of 20 feet. So far as the present short observations in the aquarium are concerned, the specimen did not show any characteristic cleaning behavior. Nevertheless, the shrimp was actually kept alive for more than six months, without any special food supply, therefore it is sure that the shrimp obtained some food by cleaning and then it is apparently an obligate cleaner.

Plumose hairs on the proximal part of the palp of the maxillule and maxilla seem to be unique to the genus Lysmata. The similar hairs are found on the proximal two segments of the endopod of the first maxilliped, too. In the so-called free living species, such as L. vittata (Stimpson) and L. multiscissa, however, only a few setae are implanted there in place of these hairs (Gordon, 1935, Kubo, 1951 and Monod, 1969). This seems to suggest that these hairs are concerned with the feeding behavior of this shrimp, though their function has not been cleared so far. 
Distribution. The present species is known to be of the circumtropical distribution: in the Pacific Ocean from the Society Islands (Randall, 1958), Hawaii (Feder, 1966), Amboina (De Man, 1888 and 1907; Holthuis, 1947), Philippines (Sakurai, personal communication), Tongking Bay (Zarenkov, 1971), Okinawa (Takeda, personal communication) ${ }^{1)}$, Kushimoto, Wakayama-ken (the present locality), Uchiura coast, Shizuoka-ken, Japan (Suzuki, personal communication) ${ }^{2)}$, in the Red Sea from the Gulf of Aqaba, Israel (Faulkner and Smith, 1970), and in the Indian Ocean from Mombasa, associated with an unidentified giant sea anemone (Bruce, 1974).

In the Atlantic Ocean, from Madeira (Gordon, 1935), Florida Keys (Limbaugh, Pederson and Chace, 1961), the Bahamas (Limbaugh, Pederson and Chace, 1961), and from Antigua Island, associated with the sea anemone, Stoichactis helianthus (Chace, 1972).

\section{REFERENGES}

Bruce, A.J., 1974. On Lysmata grabhami (Gordon), a widely distributed tropical hippolytid shrimp (Decapoda, Caridea). Crustaceana, vol. 27, pp. 107-109, 1 fig.

-, 1975 . Coral reef shrimps and their colour patterns. Endeavour, vol. 34, no. 121, pp. 23-27, figs. 1-16.

Chace, F.A.,Jr., 1972. The shrimps of the Smithsonian-Bredin Caribbean Expeditions with a summary of the West Indian shallow-water species (Crustacea: Decapoda: Natantia). Smithsonian Cont. Zool., no. 98, pp. 1-179, figs. 1-61.

Faulkner, D. and Smith, C.L., 1970. The hidden sea. pp. 1-148, 70 col. pls., Viking Press, New York.

Feder, H.M., 1966. Cleaning symbiosis in the marine environment. pp. 327-380, In: S. Mark Henry (ed.) Symbiosis, vol. 1, Academic Press, New York.

Gordon, I., 1935. On new or imperfectly known species of Crustacea Macrura. J. Linn. Soc. Lond., vol. 39, pp. 307-351, figs. 1-27.

Holthuis, L.B., 1947. The Hippolytidae and Rhynchocinetidae collected by the Siboga and Snellius Expeditions with remarks on other species. Part IX in the Decapoda of the Siboga Expedition. Siboga Exped., $39 \mathrm{a}^{8}$, pp. 1-100, figs. 1-15.

Kubo, I., 1951. Some macrurous decapod Crustacea found in Japanese waters, with descriptions of four new species. J. Tokyo Univ. Fish., vol. 38, pp. 259-289, figs. 1-16.

Limbaugh, C., Pederson, H. and Chace, F.A., Jr., 1961. Shrimps that clean fishes. Bull. mar. Sci. Gulf and Caribbean, vol. 11, pp. 237-257, figs. 1-9.

De Man, J.D., 1888. Bericht über die von Herrn Dr. J. Brock im indischen Archipel gesammelten Decapoden und Stomatopoden. Arch. Naturgesch., vol. 53, pt. 1, pp. 215-600, pls. 7-22a.

- 1907. On a collection of Crustacea, Decapoda and Stomatopoda, chiefly from the Inland Sea of Japan; with descriptions of new species. Trans. Linn. Soc. Lond. Zool., ser, 2, vol. 9, pp. 387-454, pls. 31-33.

Monod, T., 1969. Sur quatre crevettes de Nouméa (Nouvelle-Calédonie). Cah. Pac., no. 13, pp.

1) Takeda and Tateishi (1975) gave a beautiful colour photograph of this species under the Japanese name, Akasuji-moebi, from Okinawa at the depth of $18 \mathrm{~m}$ (Marine Diving, no. 32, p. 16, in Japanese).

2) Mr. Katsumi Suzuki kindly placed at my disposal his specimens collected from Enashi, Uchiura coast, Shizuoka-ken at the depth of about $30 \mathrm{~m}$. They are two females, 15.5 and $16.5 \mathrm{~mm}$ in carapace length, and agree very well with the specimen from Kushimoto mentioned above and those from other localities in their external morphology and color pattern. 
191-222, figs. 1-73.

Randall, J.E., 1958. A review of the labrid fish genus Labroides, with descriptions of two new species and notes on ecology. Pac. Sci., vol. 12, pp. 327-347, figs. 1-6, pl. 1.

Yaldwyn, J.C., 1966. Notes on the behavior in captivity of a pair of banded coral shrimps, Stenopus hispidus (Olivier). Aust. Zool., vol. 13, pt. 4, pp. 377-389, pls. 25-27.

Zarenkov, N.Z., 1971. A contribution to the fauna and geographic distribution of shrimps of the family Pandalidae and Hippolytidae. Compl. Invest. Ocean Nat., pt. 2, pp. 176-195, figs. 1-4 (in Russian). 


\section{EXPLANATION OF PLATE V}

Lysmata amboinensis (De Man) cleaning a brutal moray, Gymnothorax kikado (above) and a dragon moray eel, Muraera pardalis (below) in an aquarium. 
Publ. Seto Mar. Biol. Lab., XXII (5), 1975.

PLATE V
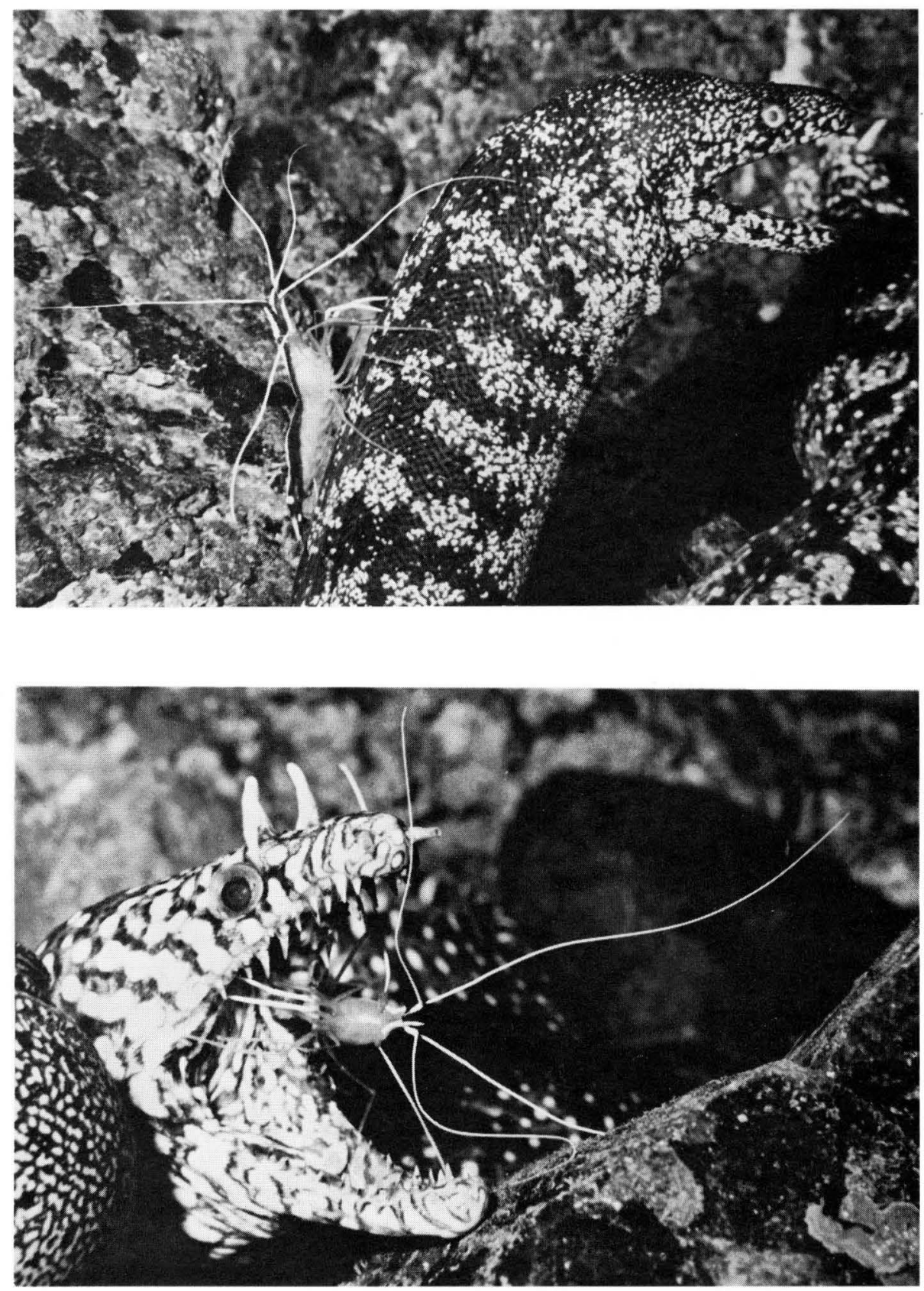

K. Hayashi: Lysmata amboinensis, Taxonomy and Biology 